\title{
Ovarian function and reproductive senescence in the rat: role of ovarian sympathetic innervation
}

\author{
Gonzalo Cruz ${ }^{1}$, Daniela Fernandois² and Alfonso H Paredes² \\ ${ }^{1}$ Laboratorio de Alteraciones Reproductivas y Metabólicas, Centro de Neurobiología y Plasticidad Cerebral (CNPC), \\ Instituto de Fisiología, Facultad de Ciencias, Universidad de Valparaíso, Valparaíso, Chile and ${ }^{2}$ Department of \\ Biochemistry and Molecular Biology, Laboratory of Neurobiochemistry, Faculty of Chemistry and Pharmaceutical \\ Sciences, Universidad de Chile, Santiago, Chile
}

Correspondence should be addressed to A H Paredes; Email: aparedes@ciq.uchile.cl

\begin{abstract}
Successful reproduction is the result of a myriad interactions in which the ovary and the ovarian follicular reserve play a fundamental role. At present, women who delay maternity until after $\mathbf{3 0}$ years of age have a decreased fertility rate due to various causes, including damaged follicles and a reduction in the reserve pool of follicles. Therefore, the period just prior to menopause, also known as the subfertile period, is important. The possibility of modulating the follicular pool and the health of follicles during this period to improve fertility is worth exploring. We have developed an animal model to study the ovarian ageing process during this subfertile period to understand the mechanisms responsible for reproductive senescence. In the rat model, we have shown that the sympathetic nervous system participates in regulating the follicular development during ovarian ageing. This article reviews the existing evidence on the presence and functional role of sympathetic nerve activity in regulating the follicular development during ovarian ageing, with a focus on the subfertile period.

Free Spanish abstract: A Spanish translation of this abstract is freely available at http://www.reproduction-online.org/content/153/2/ R59/suppl/DC1.

Reproduction (2017) 153 R59-R68
\end{abstract}

\section{Introduction}

In recent times, women frequently decide to postpone motherhood until 30 years of age or later, thus representing a sociological change compared with the previous century (Fuentes et al. 2010, Mathews \& Hamilton 2016). Pregnancy after 30 years of age is associated with a higher risk of miscarriage, hypertension and diabetes mellitus. It is also associated with an increased risk of genetic malformation of the foetus due to a greater probability of damaged follicles/oocytes (Wu et al. 2005, Schmidt et al. 2012, Waldenstrom et al. 2015). Therefore, it is important to know the sequence of events preceding menopause and the mechanisms mediating these events. Several conditions are associated with the onset of reproductive senescence in the female. However, in the human, one of the crucial factors is the loss of the pool of primordial follicles to the point of depletion (Gougeon 2003, Wilkosz et al. 2014). During the phase named the subfertile period (between 37.5 and 51 years of age), an accelerated loss of the follicular pool is observed. When the follicular pool reaches 1000 follicles, the ovary cannot maintain the hormonal feedback with the hypothalamus, and menopause is reached (close to 51 years of age) (te Velde 1998). Due to the constraints in using samples from human subjects, animal models are used to perform studies in this field. Their relatively short lifespan and the accessibility to samples from laboratory rats and mice make them a good model to study the mechanisms involved in reproductive senescence. Some authors hypothesised that in rats, the hypothalamus has a more important role than the ovary in achieving reproductive senescence (Aschheim 1965, Clemens et al. 1969, Peng \& Huang 1972, Anderson et al. 2002, Finch 2014) because when rats become infertile, a vast number of primordial follicles are still in the ovary. However, it was demonstrated that ovarian ageing also contributes to anovulation, the condition characteristic of senescence in rats (Felicio et al. 1983). As rodents prove to be a very useful model to study follicular development and ovarian ageing, it is important to know the similarities and differences in reproductive senescence between them and humans. This would allow us to correctly extrapolate data from both mice and rats to humans. In Sprague-Dawley rats, the first signs of reproductive senescence occur at approximately 8-10 months of age 
and correspond both to a decrease in the number of developing follicles and to changes in oestrous cyclicity (Peng \& Huang 1972, Acuna et al. 2009). This reduction in fertility continues gradually until 12 months of age. We characterised this period from 8 to 12 months old as the subfertile period in the rat because there is a gradual decrease in the number of developing follicles, corpora lutea and fertility (Acuna et al. 2009). From 12 months old and onward, almost no corpora lutea are observed in the ovaries of rats (Acuna et al. 2009), which is indicative of a virtual absence of ovulation. This coincides with the fact that no ova shed are found in the oviducts during oestrous from 12-months and onward (Chavez-Genaro et al. 2007). In fact, the percentage of successful pregnancies and the number of pups born per rat also decrease in the subfertile period (Fig. 1) (Jones \& Krohn 1961, Acuna et al. 2009). In addition, foetal survival also influences fertility in this period. Although foetal survival is $92.5 \%$ in young 5 -month-old rats, it gradually decreases as age increases, being only $33.8 \%$ in 11-month-old inbred rats (Mattheij \& Swarts 1991). In this review article, we analyse the follicular dynamics in the ovaries of rats throughout the period of reproductive senescence and the role of sympathetic innervation in its control, with a particular focus on the subfertile period. Finally, we discuss a potential role for ovarian kisspeptin as a regulator of follicular dynamics during ovarian ageing.

\section{Oestrous cycle of ageing rats and mice}

The daily examination of vaginal smears is commonly used to estimate the stages of the oestrous cycle in rats and mice. The differences in the proportion of different types of cells observed in the vaginal lavages reflect the changes occurring in the vaginal epithelium due to hormonal variation during the oestrous cycle

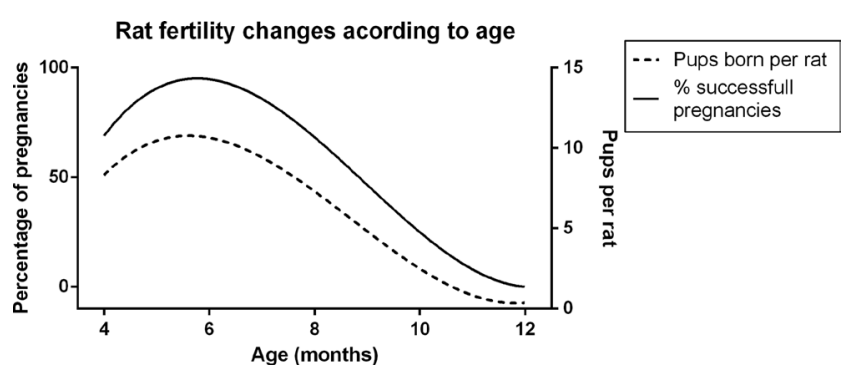

Figure 1 Representation of fertility indexes between 4 and 12 months in rats. The figure shows the average number of pups born per rat and the percentage of successful pregnancies occurring between 4 and 12 months. The information was obtained from Jones \& Krohn (1961) and Acuna and coworkers (2009). The percentage of successful pregnancies was assessed as the number of pregnancies over the number of times in which females presented positive for sperm in vaginal smears. The number of pups per rat was evaluated as the number of living pups born per mother in the first $12 \mathrm{~h}$ from delivery.
(Westwood 2008, Cora et al. 2015). In young cyclic rats and mice, the oestrous cycle is $4-5$ days in duration and comprises 4 stages: proestrus, oestrous, metestrus and diestrus. Ovulation occurs in the afternoon of proestrus. One of the first changes occurring during ageing is a lengthening of the oestrous cycle from 4 to 5 days to more than 5 days. This lengthening of the cycle is often considered irregular cyclicity and typically occurs by 8-12 months old, or even earlier, in both mice (Nelson et al. 1985, Finch 2014) and rats (Nelson et al. 1985, Sone et al. 2007). In addition, along with the changes in the cycle length, some animals do not display the logical sequence of proestrus-oestrus-metestrusdiestrus regularly; rather, they stay in the same phase for 3-5 days between regular cycles (Marcondes et al. 2002). After exhibiting irregular cycles, both rats and mice become acyclic. A representation of this cycling behaviour is schematised in Fig. 2. In both rats and mice, the end of normal ovarian cycles varies among the cohorts of animals and can be reached between 10 and 16 months old (Aschheim 1974, Merry \& Holehan 1979, Felicio et al. 1984). In one study, nearly $75 \%$ $(43 / 59)$ of the mouse cohort showed persistent epithelial cornification in their vaginal smears after ceasing to cycle (Felicio et al. 1984). This period is termed constant oestrous (CE). A CE is characterised by more than 15 days of continuous cornification cytology in the vaginal smear (Felicio et al. 1984, Westwood 2008). The CE in rats results in low and constant levels of oestradiol, estrone, testosterone, androstenedione and progesterone (with minimal levels of $20-\alpha-\mathrm{OH}-$ progesterone) compared with younger rats in the classic oestrous stage during regular cycles. Additionally, the oestradiol/progesterone ratio is increased (Huang et al. 1978, Lu et al. 1979, Westwood 2008, Fernandois et al. 2012). This low steroidogenesis is due to a low follicular development and a near absence of corpora lutea, reflecting anovulation (Acuna et al. 2009). The CE stage can be found from 10 months old and onward and is commonly followed by a period of irregular length, known as pseudopregnancy (PP) (by 19 months and onward). PP is characterised by vaginal leukocyte cytology for more than 10 days, but this can be interspersed with 1-2 days of cornified cytology or oestrous (Felicio et al. 1984). In the PP stage, both rats and mice can have a scarce number of corpora lutea, indicating that the animals may ovulate. The presence of corpora lutea is accompanied by high levels of progesterone and $20-\alpha-\mathrm{OH}$-progesterone, which leads to a decreased oestradiol/progesterone ratio (Lu et al. 1979, Sone et al. 2007, Westwood 2008). Finally, both rats and mice reach an anoestrous state (AS) by 22-25 months old (Aschheim 1961, Huang \& Meites 1975, Nelson et al. 1985, Sone et al. 2007). In AS, the rats have no cyclic activity and only vaginal leukocyte cytology accompanied by low levels of steroid hormones due to the lack of follicles (Ingram 1959, 


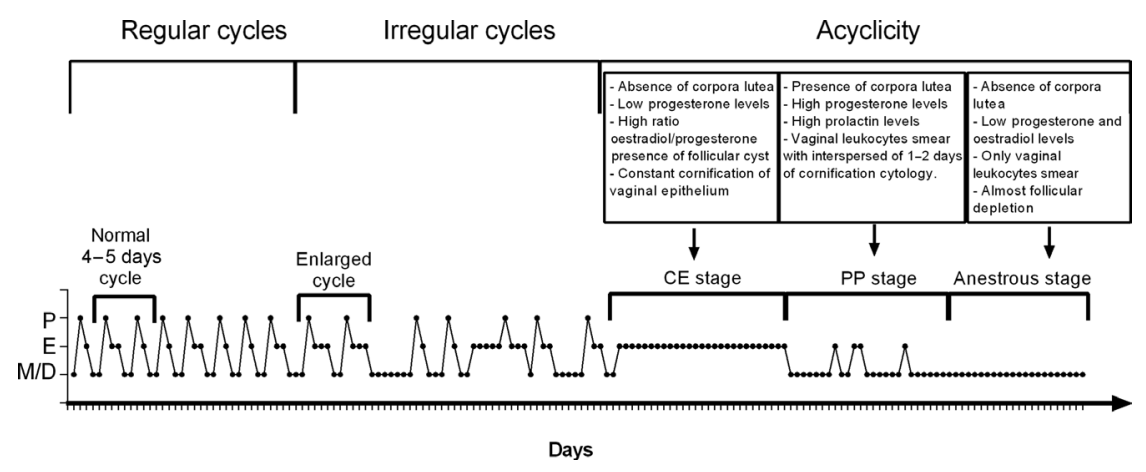

Figure 2 Schematic representation of the changes occurring in the oestrous cycle in rats or mice during reproductive ageing. The figure shows the stage of the oestrous cycle in the $Y$-axis; proestrus $(\mathrm{P})$, oestrous $(\mathrm{E})$, metestrus and diestrus $(M / D)$. The $X$-axis indicates the time course in days. A normal cycle is represented by a 4- or 5-day cycle length with the sequence P-E-M-D. The prolonged/ irregular cycles are represented by cycles of more than 5 days in length or cycles interspaced by several days of acyclicity. The acyclic stage is represented by the loss of cycles and includes constant oestrous (CE), pseudopregnancy (PP) and anoestrous. Ovarian and hormonal profiles listed above the scheme for each stage were obtained from Westwood (2008).
Aschheim 1961, Huang \& Meites 1975, Finch 2014). Not all animals change from irregular cycles to CE and then PP (Finch et al. 1984, Finch 2014). Instead, they show different sequences of events, including going directly from irregular cycling to the anoestrous stage. In one study, $25 \%$ of the mice went directly to the AS stage after the cessation of cyclicity (Felicio et al. 1984).

Although our focus in this review is analysing the ovarian changes during the subfertile period and their relationship with the sympathetic control of the ovary, it is important to mention that the hypothalamus plays a central role in the onset of reproductive senescence in mice and rats. The cessation of cyclical activity is related to the exhaustion of the follicular pool, whereas the transition from regular to irregular cycles that occurs during the subfertile period is critically influenced by the hypothalamus (Brann \& Mahesh 2005). In relation to this, GnRH pulses and hence, $\mathrm{LH}$ secretion, are attenuated in middle-aged rats (8-12-month-old) (Rubin 2000). In addition, the central response to the steroidinduced LH peak in middle-aged rats is also attenuated in comparison to young rats (Gee et al. 1984, Wise 1984, Rubin 2000, Temel et al. 2002). Interestingly, oestrogens cause epigenetic modifications, switching the Kiss 1 promoter to an active form, resulting in an increase in AVPV-specific Kiss 1 gene expression (Tomikawa et al. 2012). Thus, the lower oestradiol levels and the low sensitivity to oestradiol may be the cause of the reduction in kisspeptin expression (Kermath et al. 2014) and, consequently, irregular and lower $\mathrm{GnRH} / \mathrm{LH}$ surges in aged rats. This suggestion is supported by the fact that kisspeptin infusion directly into the medial preoptic area restores the attenuated $\mathrm{LH}$ surge in middle-aged rats (Neal-Perry et al. 2009). In addition to the failure in the kisspeptin system, other mechanisms could explain the alteration in $\mathrm{GnRH} / \mathrm{LH}$ secretion. For further reading on this topic, we suggest the following works: (Brann \& Mahesh 2005, Yin \& Gore 2006, Kermath \& Gore 2012).

\section{Follicular development during the subfertile period in rats}

The ovarian reserve of primordial follicles declines with increasing age in different mammals, including the rat (Mandl \& Shelton 1959, Jones \& Krohn 1961, Almeida et al. 2012, Atkins et al. 2014). In humans, it has been estimated, using mathematical models that the rate of follicular loss during life occurs as a biphasic exponential rate of decay. This loss of follicles accelerates when the subfertile period that precedes menopause is reached (Richardson et al. 1987, Faddy et al. 1992, Hale et al. 2014). However, other authors state that the follicular decay is constantly accelerating and that the increase in follicular loss during the subfertile period may be an experimental issue (Hansen et al. 2008). In mice, it has been proposed that the decline in the number of primordial follicles occurs in a constant proportion to the existing number of follicles (Jones \& Krohn 1961). In addition to the loss of primordial follicles, a feature of ovarian ageing is the change in the expression profile of some key genes between aged and young primordial follicles. In summary, some altered genes include Brac1, Rad51, Ercc2 H2ax, GRP78, FIGNL1, Calreticulin, BOK and Peroxiredoxin 2 and 3 (Govindaraj \& Rao 2015, Govindaraj et al. 2015). Altogether, the change in the expression of these factors could explain the decrease in DNA repair, protein folding and antiapoptotic properties of aged primordial follicles. Therefore, the fate of aged primordial follicles could be altered in comparison with a primordial follicle in a younger animal. Then, the function and development of the follicle in subsequent stages could be affected. Independent of this, the recruitment of primordial follicles into the growing pool of follicles does not depend on the cyclic activity of gonadotropins. Instead, it appears to be regulated by a coordinated machinery of paracrine factors, which exert an inhibitory control of primordial follicle activation (Adhikari \& Liu 2009). In the review by McGee and Hsueh (2000), it is suggested 
to denominate 'initial recruitment' as the transition of a primordial follicle into a primary follicle to differentiate this process from the cyclic recruitment of antral follicles performed by FSH.

If the distribution of developing follicles is analysed, the number of small developing follicles (preantral stage) are observed to decrease by more than half by 8 months of age, and this number of follicles is maintained relatively constantly until 14 months of age (Acuna et al. 2009). Meanwhile, the number of antral follicles also decreases from 8 months old and onward (Lerner et al. 1990, Acuna et al. 2009). However, it has been demonstrated that the number of antral follicles $>400 \mu \mathrm{m}$ and preovulatory follicles remains unchanged (Jones \& Krohn 1961, Lerner et al. 1990, Fernandois et al. 2016). This increase in the proportion of largersized follicles indicates that ovaries of aged rats within the subfertile period utilise primordial follicles more efficiently. They have low initial recruitment and low growth of small follicles but have a proportionally higher number of follicles reaching the preovulatory stage at the proestrus phase (Jones \& Krohn 1961, Peluso et al. 1979). However, this higher proportion of preovulatory follicles is not proportionally reflected in more ovulation as the number of corpora lutea decreases with age and is virtually absent from 12 months of age, despite antral follicles continuing to grow (Chavez-Genaro et al. 2007, Acuna et al. 2009), indicating that preovulatory follicles take a pathway alternative to ovulation. This alternative pathway could be the formation of precystic and cystic structures (as discussed below). However, together with the decrease in healthy preantral and antral follicles, a decrease in the atretic follicle count in ageing rats from 12 months old has been characterised (Peluso et al. 1979, Acuna et al. 2009). In addition, Nishijima and coworkers (2013) showed that atretic follicles begin to increase from 18 months old and onward in rats. As the decrease in healthy follicles in the subfertile period is not explained by the process of atresia, an alternative explanation is required. A lower recruitment of follicles and the deviation of follicles to abnormal structures should explain this low follicular development. The presence of luteinized follicles has been observed in ageing rats, structures that are abnormal in young rats (Acuna et al. 2009). Luteinized follicles are characterised by the presence of luteinized granulosa cells (they contain a big cytoplasm similar to luteal cells), and an antral cavity (although there is no oocyte) (Smirnova 1964, Moon et al. 1993). These alternative structures, which appear in the ovary of rats during the subfertile period, may produce hormones and paracrine factors, which potentially affect the development of other follicles.

The lower number of developing follicles is probably responsible for the low serum levels of steroid hormones observed in middle-aged rats, particularly oestradiol (Lu et al. 1979, Anzalone et al. 2001,
Acuna et al. 2009, Fernandois et al. 2012). This could account for the prolonged or irregular cycles observed during the subfertile period as low numbers of antral follicles lead to an extended follicular phase in which the levels of oestradiol sufficient to induce LH secretion are reached later or not at all. This may manifest in additional days in the diestrus or oestrous stage in the vaginal smear.

\section{Ovulation and spontaneous follicular cyst formation during the subfertile period in rats}

It is well known that in the rat, ovulatory capacity and fertility are decreased from 8 to 10 months old and onward (Jones \& Krohn 1961, Mattheij \& Swarts 1991, Niggeschulze \& Kast 1994, Chavez-Genaro et al. 2007, Acuna et al. 2009). This can be evaluated by counting the number of corpora lutea present in the ovary, the number of ovulated oocytes and the number of pups born per litter at different ages. This period has been characterised by a dramatic decrease in the number of corpora lutea with increasing age from 10 to 12 months old (Acuna et al. 2009), even though the number of preovulatory follicles is maintained (Peluso et al. 1979). We demonstrated that 12-month-old Sprague-Dawley rats have a very low number of corpora lutea, along with an increase in type III follicles and follicular cysts (Acuna et al. 2009). Type III follicles are structures with very similar morphology to preovulatory follicles but can be found in the oestrous stage, indicating that these follicles did not ovulate after the LH preovulatory peak. Type III follicles were first described by Brawer and coworkers in the rat model of polycystic ovary syndrome induced by oestradiol valerate. Histologically, they are formed by approximately 5 layers of granulosa cells, an invagination of the theca layer, loss or discontinuation of the basal membrane and usually a size bigger than $750 \mu \mathrm{m}$ in diameter. Regarding the oocyte nucleus, an apparently healthy germinal vesicle can be observed (Brawer et al. 1989, Lara et al. 2000, Fernandois et al. 2012). These types of follicles lose their oocytes and change into follicular cysts, which do not contain oocytes and have only one layer of granulosa cells. Although both type III follicles and follicular cysts are almost absent in young control rats, they are typically observed in rat models of polycystic ovary syndrome induced by oestrogens and in aged rats (Brawer et al. 1989, Acuna et al. 2009, Fernandois et al. 2012, 2016). Comparing the rat model of oestradiol valerate-induced polycystic ovaries with ageing rats could give us insights into the mechanisms that control ovulation and cystic structure generation during ageing. It is possible that preovulatory follicles are deviating from ovulation into the formation of cysts (Convery et al. 1990, Lara et al. 2000, Fernandois et al. 2012). In the model of polycystic ovaries induced by oestradiol exposure, there is an increase in the content and release of norepinephrine 
(NE) in the ovary (see below). This led us to investigate the role of sympathetic activity in ovarian ageing.

\section{Sympathetic innervation and ovarian ageing}

The sympathetic innervation of the ovary has been described using different techniques in humans, monkeys and rodents (mice and rats) (Stefenson et al. 1981, Burden et al. 1983, 1985, Gerendai et al. 1995, 1998, 2002). Using histofluorescence, nerve fibres, mainly noradrenergic, were shown to be present in the ovary (Burden etal. 1983, 1985). These were associated with not only the vasculature but also the ovarian follicles, which were densely marked around the thecal zone (Stefenson et al. 1981). The mapping of the nerve projection from the sympathetic pathway was studied in rats with retrograde viral tracers by Gerendai and coworkers. In these experiments, a hypothalamic-spinal medullaganglion-ovary pathway was elucidated (Gerendai et al. $1995,1998,2002)$. In rats, the sympathetic nerve fibres projecting to the ovary come from the coeliac ganglion via two different routes: the nerve plexus of the ovary, whose nerve fibres project mainly to the ovarian blood vessels, and the superior ovarian nerve (SON), whose fibres project into the follicles (Baljet \& Drukker 1979, Lawrence \& Burden 1980). It was demonstrated that cholinergic ganglionic stimulation during oestrous increases the $\mathrm{NE}$ in the ovarian compartment compared to that in control (Hanada et al. 2011, Daneri et al. 2013). Hanada and coworkers (2011) have shown that the nerve fibres associated with blood vessels regulating ovarian blood flow are mainly unmyelinated C fibres, which are maintained in number, size, conduction ability and vasoconstrictor response in aged PP rats compared to that in young rats. This means that the sympathetic adrenergic vasoconstrictor response in the ovary is well preserved in rats aged 28-31 months old. In addition to regulating ovarian blood flow, extrinsic ovarian innervation directly regulates steroidogenesis (Aguado \& Ojeda 1984) and follicular development (Lara et al. 1993, Moran et al. 2000, Rosa et al. 2003, Doganay et al. 2010, Zhang et al. 2010). Both $\alpha$ and $\beta$ adrenergic receptors are expressed in the ovarian follicles (Aguado et al. 1982, Barria et al. 1993, Itoh \& Ishizuka 2005, Fernandois et al. 2012), and direct effects of NE on follicles could be produced by $\alpha 1$ and $\beta 2$ adrenergic receptor stimulation (Laszlovszky \& Erdo 1983, Itoh \& Ishizuka 2005). Interestingly, both sympathetic activity and the density of $\beta$ receptors in the ovary change with the oestrous cycle in the rat (Lara et al. 2002). Regarding follicular development, the surgical section of the ovarian superior nerve (SON) in pigs increases the number of small follicles $(<3 \mathrm{~mm})$ and decreases the number of large follicles $(>7 \mathrm{~mm})$. This change in the follicular population is associated with a decrease in the content of steroid hormones in the follicular fluid (Jana et al. 2007). A similar effect is found in rats, where a bilateral denervation of the SON decreases the serum level of oestradiol, progesterone and the number of developing follicles. In addition, when a unilateral denervation of the SON was assessed, a decrease in the number of follicles was observed in the denervated ovary and a compensation (observed as an increase in the number of follicles) was observed in the innervated ovary (Moran et al. 2000). In addition, it has been demonstrated that the sympathetic innervation of follicles influences follicular maturation/growth (Mayerhofer et al. 1997, Paredes et al. 2011), steroidal secretion (Hernandez et al. 1988, Barria et al. 1993) and ovulation (Kannisto et al. 1985). In fact, an increase in ovarian sympathetic activity is observed in rats with an oestradiol-induced polycystic ovary condition. In these rats, alterations in follicular growth and ovulation are observed (Lara et al. 1993, 2000, Rosa et al. 2003). As reviewed by Lansdown and Rees (2012), polycystic ovary syndrome (PCOS) is associated with an increased noradrenergic tone directly in the ovary. Some PCOS women also display a generalised increase in sympathetic tone activity, which offers a possibility for intervention by lowering the sympathetic outflow using strategies such as drugs, surgery or acupuncture (Lansdown \& Rees 2012).

The role of sympathetic innervation in ovarian ageing has been studied by different groups, including us. An early study demonstrated that old Wistar rats (24 months old) have a decrease in the ovarian concentration of NE compared to young (3 months old) rats (Ferrante et al. 1990). It is possible that the very low number of follicles present in the ovaries of rats at this age is not enough to maintain an adequate production of neurotrophic factors, principally nerve growth factor (NGF), which is known to participate in the maintenance of noradrenergic fibres (Lara et al. 1990b). More recent studies have been focused on the transition of young cycling rats through the subfertile period. In these rats, we and others demonstrated an increase in the ovarian concentration of NE with increasing age, without changes in plasma NE levels (Lerner et al. 1990, Chavez-Genaro et al. 2007, Acuna et al. 2009). This increase in the content of NE is accompanied by an increase in the release of NE into the ovary in rats 12 and 14 months old compared to that in 6-month-old rats, demonstrating an increased adrenergic tone with increasing age (Acuna et al. 2009). Additionally, we measured a decreasing ovarian density of $\beta$ adrenergic receptors with age, along with an inverse increase in adrenergic tone, in rats (Fig. 3). Interestingly, in humans, an increase in nerve fibres in the ovary related to ageing has also been demonstrated (Heider et al. 2001). More recent studies have confirmed that post-menopausal women have higher nerve activity, baseline plasma NE levels and reduced $\beta$-adrenergic receptor responsiveness 


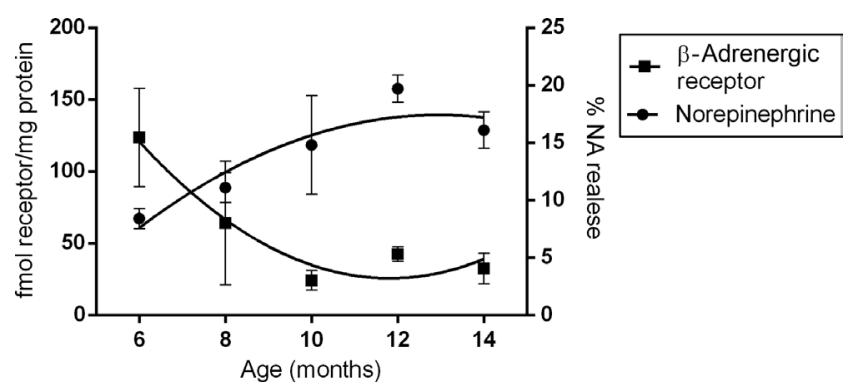

Figure 3 Concentration of ovarian $\beta$-adrenergic receptors and NE release according to age. Data of $\beta$-adrenergic receptors are unpublished work, and data of ovarian NE release were obtained from Acuna and coworkers (2009). The ovarian $\beta$-adrenergic receptor content was determined by a radio-ligand binding technique and is expressed as fmol dihydroalprenolol bound/mg of membrane protein. Ovarian NE release was determined as the percentage of ${ }^{3} \mathrm{H}-\mathrm{NE}$ released after $1 \mathrm{~min}$ of electric stimulation from the total of ${ }^{3} \mathrm{H}-\mathrm{NE}$ previously incorporated into ovaries (NE dpm $\times 1000 /$ ovary). The data are plotted as the mean \pm S.E.M.

compared to premenopausal women (Sherwood et al. 2010, Hogarth et al. 2011).

As the adrenergic tone of the ovary is increased during the subfertile period, we believe that NE contributes to the changes in follicular development observed in the ovary during the transition through 8-12 months old until the infertile period. As discussed previously, there is also an increase in the adrenergic tone of the ovary in the model that uses oestradiol valerate administration (Lara et al. 1993). In this model, it is possible to observe the same changes in follicular dynamics that are seen in the ovaries of ageing rats (Lara et al. 2002, Acuna et al. 2009, Cruz et al. 2012). Within these changes, we observe a decrease in preantral and antral follicles, a decrease (or absence) of corpora lutea and the appearance of type III and cystic follicles. In this model of polycystic ovary, the denervation of the ovary by sectioning the SON leads to a partial recovery of follicular development (Rosa et al. 2003). As around the 8-10-month-old stage the ovary still has enough primordial follicles capable of developing into preovulatory ones, we believe that the development of abnormal structures (i.e., type III follicles and cysts) is due to a deviation of antral or preovulatory follicles under the influence of increased noradrenergic tone. Using this hypothesis, we tried to reverse the polycystic condition associated with low follicular development and low plasma steroidal hormones by administering the $\beta$ adrenergic blocker propranolol and hence, increase fertility within the subfertile period. We found that daily administration of propranolol $(5 \mathrm{mg} /$ $\mathrm{kg}$ of body weight) for 2 months in 8- and 10-monthold rats increases the number of healthy antral follicles and increases the number of corpora lutea in the ovary. Along with this improvement in follicular development and ovulation, propranolol decreased the number of follicular cysts. These changes in follicular development were functionally associated with an increase in serum progesterone, androgens and oestradiol. Additionally, the $\beta$ adrenergic blocker improved the pattern of the oestrous cycle by increasing the number of 4-5-day cycles during the treatment (Fernandois et al. 2012). However, denervation with guanethidine for 7 days increased the proportion of healthy antral follicles, but not ovulation (number of ova shed) in 12- and 18-month-old rats (Chavez-Genaro et al. 2007). In this study, guanethidine was administered, and the rats were immediately killed. However, 7 days (less than 2 oestrous cycles) was not enough time to permit the healthy antral follicles to reach the ovulation stage. This explains the differences in the results with those of the previously described study.

In young rats, $\beta$-adrenergic stimulation of the ovary increases follicular development (Mayerhofer et al. 1997), whereas pharmacological denervation delays the development of follicles (Lara et al. 1990a). This effect of adrenergic stimulation on follicular development is, in part, produced by NE stimulation on FSHR expression (Mayerhofer et al. 1997). If this also occurs in ageing rats, which are under a hyperadrenergic tone, we would expect an increase in follicular development. However, this does not seem to be the case if we consider the net number of growing follicles in rats during the subfertile period. Recently, we found that sympathetic nerves regulate the paracrine factor kisspeptin (KP) in the ovary and that KP modulates the effects of sympathetic nerves on ovarian function, which could explain why the increase in the sympathetic tone is not reflected in higher follicular growth (Fernandois et al. 2016).

\section{Role of ovarian kisspeptin in ovarian ageing and its relation to sympathetic innervation of the ovary}

The kisspeptins are a family of peptides resulting from differential proteolytic processing of a single precursor (Pinilla et al. 2012). In humans, four biologically active peptides have been described, whereas in rats, only two peptides have been detected (UniProt 2015). All these peptides share the last 10 amino acids of the C-terminal region, the region responsible for binding to the Kisspeptin receptor (KISS1R or GPR54) (Kotani et al. 2001, Muir et al. 2001, Messager et al. 2005). Hypothalamic KP is considered a master regulator of the gonadotropic axis and is critical for the onset of puberty in mammals (Pinilla et al. 2012). Knockout (KO) mice of the kisspeptin receptor $\left(\mathrm{GPR} 54^{---}\right)($Colledge 2009) and the novel Kiss 1 $\mathrm{KO}$ rats (Uenoyama et al. 2015) do not reach puberty and are infertile due to the absence of gonadotropin secretion. KP and its receptor KISS1R are expressed in the ovary of different species including humans, rats and mice, and their expression and immunolocalisation are in theca cells (TCs) (Castellano et al. 2006, Gaytan et al. 2009, Zhou et al. 2014) and granulosa cells (GCs) (Ricu et al. 2012, Laoharatchatathanin et al. 2015). 
In addition, KP mRNA levels have been demonstrated to change throughout the oestrous cycle in the rat ovary, being at their highest during proestrus (Castellano et al. 2006, Laoharatchatathanin et al. 2015).

We recently found that intraovarian KP increases as age increases during the subfertile period in the rat (Fernandois et al. 2016). Along the same lines, a very recent study confirmed our results demonstrating that ovarian mRNA levels of Kiss 1 and its receptor Kiss $1 R$ increase in aged mice compared to that in younger mice. Although the authors failed to measure ovarian kisspeptin mRNA in women GCs, they found that ovarian Kiss1R mRNA levels increase according to age (Merhi et al. 2016). Interestingly, ovarian KP has a positive correlation with ovarian NE release during the subfertile period in the rat (Fernandois et al. 2016). This is in agreement with a previous study from our group demonstrating that KP expression of the ovary increases after $\beta$ adrenergic stimulation in vitro (Ricu et al. 2012). Considering that chronic administration of propranolol improves the development of ovarian follicles (Fernandois et al. 2012) and that ovarian KP is under the control of sympathetic innervation, we thought that KP could be decreasing the follicular development during ageing. To test this hypothesis, we designed experiments using in vivo stimulation with $\mathrm{KP}$ or its antagonist P234 directly in the ovary in rats during 28 days within the subfertile period. The results showed that KP administration decreases the number of antral follicles, whereas P234 increases it (Fernandois et al. 2016). Moreover, both the sympathetic denervation of the ovary and propranolol administration decreases KP in the ovary and accelerates follicular development (D Fernandois, G Cruz, EK Na, HE Lara and AH Paredes 2016, manuscript accepted). Consistent with these findings, in vitro experiments demonstrated that KP prevents the induction of FSHR expression by the $\beta$ adrenergic agonist isoproterenol (Fernandois et al. 2016). Therefore, it is understandable that Kiss1R haplo-insufficient mice $\left(\mathrm{Kiss}^{\mathrm{r}} \mathrm{r}^{+-}\right)$present an early loss of oocytes, primordial follicles and antral follicles by 8 months old, showing that these mice present a premature ovarian failure despite maintaining circulating gonadotropin levels (Gaytan et al. 2014). Likewise, Kiss $1 R \mathrm{KO}$ mice with reinsertion of the Kiss1R gene in $\mathrm{GnRH}$ neurons show premature ovarian ageing, even when there is a normally functioning hypothalamic kisspeptin system (Leon et al. 2016). This could mean that the lack of inhibitory action of KP on FSHR expression induced by the sympathetic system leads to an enhanced loss of follicles through life and could cause premature ovarian senescence. This hypothesis, however, must be confirmed.

\section{Conclusion}

In the present review, we show evidence attributing a role to sympathetic innervation on follicular dynamics during the subfertile period in the rat. The mechanisms underlying this sympathetic control are complex and still should be fully elucidated. In particular, it would be interesting to observe which follicular structure present in the ovaries of senescent rats expresses adrenergic receptors and responds to NE modulation of KP secretion. The capacity of a $\beta$ blocker and a KP antagonist to increase follicular growth during the subfertile period in rats offers a new possibility to pharmacologically intervene in the pool of developing follicles during ageing, with the aim of improving fertility and its outcome.

\section{Declaration of interest}

The authors declare that there is no conflict of interest that could be perceived as prejudicing the impartiality of the research reported.

\section{Funding}

Authors of this manuscript are supported by FONDECYTChile (grant numbers: G C 11130707 and A P 1120147) and CONICYT grant for doctoral thesis (number: 21120454, to $\mathrm{DF}$ ).

\section{References}

Acuna E, Fornes R, Fernandois D, Garrido MP, Greiner M, Lara HE \& Paredes AH 2009 Increases in norepinephrine release and ovarian cyst formation during ageing in the rat. Reproductive Biology and Endocrinology 7 64. (doi:10.1186/1477-7827-7-64)

Adhikari D \& Liu K 2009 Molecular mechanisms underlying the activation of mammalian primordial follicles. Endocrine Reviews 30 438-464. (doi:10.1210/er.2008-0048)

Aguado LI \& Ojeda SR 1984 Prepubertal ovarian function is finely regulated by direct adrenergic influences. Role of noradrenergic innervation. Endocrinology 114 1845-1853. (doi:10.1210/endo-114-5-1845)

Aguado LI, Petrovic SL \& Ojeda SR 1982 Ovarian beta-adrenergic receptors during the onset of puberty: characterization, distribution, and coupling to steroidogenic responses. Endocrinology 110 1124-1132. (doi:10.1210/endo-110-4-1124)

Almeida DV, Santos RR, Scalercio SR, Leao DL, Haritova A, Oskam IC \& Domingues SF 2012 Morphological and morphometrical characterization, and estimation of population of preantral ovarian follicles from senile common squirrel monkey (Saimiri sciureus). Animal Reproduction Science 134 210-215. (doi:10.1016/j.anireprosci.2012.08.028)

Anderson CP, Rozovsky I, Stone DJ, Song Y, Lopez LM \& Finch CE 2002 Aging and increased hypothalamic glial fibrillary acid protein (GFAP) mRNA in F344 female rats. Dissociation of GFAP inducibility from the luteinizing hormone surge. Neuroendocrinology 76 121-130. (doi:10.1159/000064429)

Anzalone CR, Hong LS, Lu JK \& LaPolt PS 2001 Influences of age and ovarian follicular reserve on estrous cycle patterns, ovulation, and hormone secretion in the Long-Evans rat. Biology of Reproduction 64 1056-1062. (doi:10.1095/biolreprod64.4.1056)

Aschheim P 1961 Repeated pseudogestation in senile rats. Comptes Rendus Hebdomadaires des Séances de l'Académie des Sciences 253 1988-1990.

Aschheim P 1965 Reactivation of the ovary of senile rats in permanent estrus by means of gonadotropic hormones or placement in darkness. Comptes Rendus Hebdomadaires des Séances de l'Académie des Sciences. Série D: Sciences naturelles 260 5627-5630.

Aschheim P 1974 A biological aging test for the central regulation of the estrous cycle in the rat. Its first application. Experientia 30213. 
Atkins HM, Willson CJ, Silverstein M, Jorgensen M, Floyd E, Kaplan JR \& Appt SE 2014 Characterization of ovarian aging and reproductive senescence in vervet monkeys (Chlorocebus aethiops sabaeus). Comparative Medicine 64 55-62.

Baljet B \& Drukker J 1979 The extrinsic innervation of the abdominal organs in the female rat. Acta Anatomica 104 243-267. (doi:10.1159/000145073)

Barria A, Leyton V, Ojeda SR \& Lara HE 1993 Ovarian steroidal response to gonadotropins and beta-adrenergic stimulation is enhanced in polycystic ovary syndrome: role of sympathetic innervation. Endocrinology 133 2696-2703.

Brann DW \& Mahesh VB 2005 The aging reproductive neuroendocrine axis. Steroids 70 273-283. (doi:10.1016/j.steroids.2004.12.008)

Brawer J, Richard M \& Farookhi R 1989 Pattern of human chorionic gonadotropin binding in the polycystic ovary. American Journal of Obstetrics and Gynecology 161 474-480. (doi:10.1016/00029378(89)90544-9)

Burden HW, Leonard M, Smith CP \& Lawrence IE Jr 1983 The sensory innervation of the ovary: a horseradish peroxidase study in the rat. Anatomical Record 207 623-627. (doi:10.1002/ar.1092070410)

Burden HW, Lawrence IE Jr \& Louis TM 1985 The adrenergic innervation of the guinea pig ovary during prenatal and postnatal periods. Acta Anatomica 122 193-196. (doi:10.1159/000146001)

Castellano JM, Gaytan M, Roa J, Vigo E, Navarro VM, Bellido C, Dieguez C, Aguilar E, Sanchez-Criado JE, Pellicer A et al. 2006 Expression of KiSS-1 in rat ovary: putative local regulator of ovulation? Endocrinology 147 4852-4862. (doi:10.1210/en.2006-0117)

Clemens JA, Amenomori Y, Jenkins T \& Meites J 1969 Effects of hypothalamic stimulation, hormones, and drugs on ovarian function in old female rats. Proceedings of the Society for Experimental Biology and Medicine 132 561-563. (doi:10.3181/00379727-132-34260)

Colledge WH 2009 Transgenic mouse models to study Gpr54/kisspeptin physiology. Peptides 30 34-41. (doi:10.1016/j.peptides.2008.05.006)

Convery M, McCarthy GF \& Brawer JR 1990 Remission of the polycystic ovarian condition (PCO) in the rat following hemiovariectomy. Anatomical Record 226 328-336. (doi:10.1002/ar.1092260309)

Cora MC, Kooistra L \& Travlos G 2015 Vaginal cytology of the laboratory rat and mouse: review and criteria for the staging of the estrous cycle using stained vaginal smears. Toxicologic Pathology 43 776-793. (doi:10.1177/0192623315570339)

Cruz G, Barra R, Gonzalez D, Sotomayor-Zarate R \& Lara HE 2012 Temporal window in which exposure to estradiol permanently modifies ovarian function causing polycystic ovary morphology in rats. Fertility and Sterility 98 1283-1290. (doi:10.1016/j.fertnstert.2012.07.1060)

Chavez-Genaro R, Lombide P, Dominguez R, Rosas P \& Vazquez-Cuevas F 2007 Sympathetic pharmacological denervation in ageing rats: effects on ovulatory response and follicular population. Reproduction Fertility and Development 19 954-960. (doi:10.1071/RD07075)

Daneri C, Orozco AV, Bronzi D, Mohn C, Rastrilla AM \& Sosa ZY 2013 Involvement of the ganglion cholinergic receptors in gonadotropin-releasing hormone, catecholamines, and progesterone release in the rat ovary. Fertility and Sterility 99 2062-2070. (doi:10.1016/j.fertnstert.2013.02.037)

Doganay M, Simsek A, Tapisiz OL, Mulazimoglu BS, Yumusak N \& Gungor T 2010 Superior ovarian nerve (SON) transection leads to stunted follicular maturation: a histomorphologic and morphometric analysis in the rat model. Fertility and Sterility 93 1711-1714. (doi:10.1016/j. fertnstert.2009.09.026)

Faddy MJ, Gosden RG, Gougeon A, Richardson SJ \& Nelson JF 1992 Accelerated disappearance of ovarian follicles in mid-life: implications for forecasting menopause. Human Reproduction 7 1342-1346.

Felicio LS, Nelson JF, Gosden RG \& Finch CE 1983 Restoration of ovulatory cycles by young ovarian grafts in aging mice: potentiation by long-term ovariectomy decreases with age. PNAS 80 6076-6080. (doi:10.1073/ pnas.80.19.6076)

Felicio LS, Nelson JF \& Finch CE 1984 Longitudinal studies of estrous cyclicity in aging C57BL/6J mice: II. Cessation of cyclicity and the duration of persistent vaginal cornification. Biology of Reproduction 31 446-453. (doi:10.1095/biolreprod31.3.446)

Fernandois D, Lara HE \& Paredes AH 2012 Blocking of beta-adrenergic receptors during the subfertile period inhibits spontaneous ovarian cyst formation in rats. Hormone and Metabolic Research 44 682-687. (doi:10.1055/s-0032-1304607)
Fernandois D, Na E, Cuevas F, Cruz G, Lara HE \& Paredes AH 2016 Kisspeptin is involved in ovarian follicular development during aging in rats. Journal of Endocrinology 228 161-170. (doi:10.1530/JOE15-0429)

Ferrante F, Bronzetti E, Cavallotti C, Ricci A \& Amenta F 1990 The noradrenergic innervation of the ovary in old rats. Mechanisms of Ageing and Development 54 55-61. (doi:10.1016/0047-6374(90)90015-8)

Finch CE 2014 The menopause and aging, a comparative perspective. Journal of Steroid Biochemistry and Molecular Biology 142 132-141. (doi:10.1016/j.jsbmb.2013.03.010)

Finch CE, Felicio LS, Mobbs CV \& Nelson JF 1984 Ovarian and steroidal influences on neuroendocrine aging processes in female rodents. Endocrine Reviews 5 467-497. (doi:10.1210/edrv-5-4-467)

Fuentes A, Jesam C, Devoto L, Angarita B, Galleguillos A, Torres A \& Mackenna A 2010 Association between motherhood postponement and socioeconomic status. Revista Medica de Chile 138 1240-1245. (doi:10.4067/S0034-98872010001100005)

Gaytan F, Garcia-Galiano D, Dorfman MD, Manfredi-Lozano M, Castellano JM, Dissen GA, Ojeda SR \& Tena-Sempere M 2014 Kisspeptin receptor haplo-insufficiency causes premature ovarian failure despite preserved gonadotropin secretion. Endocrinology 155 3088-3097. (doi:10.1210/en.2014-1110)

Gaytan F, Gaytan M, Castellano JM, Romero M, Roa J, Aparicio B, Garrido N, Sanchez-Criado JE, Millar RP, Pellicer A et al. 2009 KiSS-1 in the mammalian ovary: distribution of kisspeptin in human and marmoset and alterations in KiSS-1 mRNA levels in a rat model of ovulatory dysfunction. American Journal of Physiology: Endocrinology and Metabolism 296 E520-E531. (doi:10.1152/ajpendo.90895.2008)

Gee DM, Flurkey K, Mobbs CV, Sinha YN \& Finch CE 1984 The regulation of luteinizing hormone and prolactin in C57BL/6J mice: effects of estradiol implant size, duration of ovariectomy, and aging. Endocrinology 114 685-693. (doi:10.1210/endo-114-3-685)

Gerendai I, Csaba Z, Voko Z \& Csernus V 1995 Involvement of a direct neural mechanism in the control of gonadal functions. Journal of Steroid Biochemistry and Molecular Biology 53 299-305. (doi:10.1016/09600760(95)00067-A)

Gerendai I, Toth IE, Boldogkoi Z, Medveczky I \& Halasz B 1998 Neuronal labeling in the rat brain and spinal cord from the ovary using viral transneuronal tracing technique. Neuroendocrinology 68 244-256. (doi:10.1159/000054372)

Gerendai I, Kocsis K \& Halasz B 2002 Supraspinal connections of the ovary: structural and functional aspects. Microscopy Research and Technique 59 474-483. (doi:10.1002/jemt.10225)

Gougeon A 2003 Chapter 2 - Dynamics of human follicular growth: morphologic, dynamic, and functional aspects A2. In The Ovary, Second Edition, pp. 25-IV. Eds PCK Leung \& EY Adashi. San Diego, CA, USA: Academic Press.

Govindaraj V \& Rao AJ 2015 Comparative proteomic analysis of primordial follicles from ovaries of immature and aged rats. Systems Biology in Reproductive Medicine 61 367-375. (doi:10.3109/19396368.2015. 1077903)

Govindaraj V, Keralapura Basavaraju R \& Rao AJ 2015 Changes in the expression of DNA double strand break repair genes in primordial follicles from immature and aged rats. Reproductive Biomedicine Online 30 303-310. (doi:10.1016/j.rbmo.2014.11.010)

Hale GE, Robertson DM \& Burger HG 2014 The perimenopausal woman: endocrinology and management. Journal of Steroid Biochemistry and Molecular Biology 142 121-131. (doi:10.1016/j. jsbmb.2013.08.015)

Hanada T, Uchida S, Hotta H \& Aikawa Y 2011 Number, size, conduction, and vasoconstrictor ability of unmyelinated fibers of the ovarian nerve in adult and aged rats. Autonomic Neuroscience 164 6-12. (doi:10.1016/j. autneu.2011.05.001)

Hansen KR, Knowlton NS, Thyer AC, Charleston JS, Soules MR \& Klein NA 2008 A new model of reproductive aging: the decline in ovarian nongrowing follicle number from birth to menopause. Human Reproduction 23 699-708. (doi:10.1093/humrep/dem408)

Heider U, Pedal I \& Spanel-Borowski K 2001 Increase in nerve fibers and loss of mast cells in polycystic and postmenopausal ovaries. Fertility and Sterility 75 1141-1147. (doi:10.1016/S0015-0282(01)01805-2)

Hernandez ER, Jimenez JL, Payne DW \& Adashi EY 1988 Adrenergic regulation of ovarian androgen biosynthesis is mediated via beta 
2-adrenergic theca-interstitial cell recognition sites. Endocrinology 122 1592-1602. (doi:10.1210/endo-122-4-1592)

Hogarth AJ, Graham LN, Corrigan JH, Deuchars J, Mary DA \& Greenwood JP 2011 Sympathetic nerve hyperactivity and its effect in postmenopausal women. Journal of Hypertension 29 2167-2175. (doi:10.1097/HJH.0b013e32834b8014)

Huang HH \& Meites J 1975 Reproductive capacity of aging female rats. Neuroendocrinology 17 289-295. (doi:10.1159/000122367)

Huang HH, Steger RW, Bruni JF \& Meites J 1978 Patterns of sex steroid and gonadotropin secretion in aging female rats. Endocrinology 103 1855-1859. (doi:10.1210/endo-103-5-1855)

Ingram DL 1959 The vaginal smear of senile laboratory rats. Journal of Endocrinology 19 182-188. (doi:10.1677/joe.0.0190182)

Itoh MT \& Ishizuka B 2005 alpha1-Adrenergic receptor in rat ovary: presence and localization. Molecular and Cellular Endocrinology 240 58-63. (doi:10.1016/j.mce.2005.05.012)

Jana B, Dzienis A, Wojtkiewicz J, Kaczmarek M \& Majewski M 2007 Surgical denervation of porcine ovaries during the middle luteal phase of the oestrous cycle changes their morphology and steroidogenic activity. Acta Veterinaria Hungarica 55 107-122. (doi:10.1556/AVet.55.2007.1.11)

Jones EC \& Krohn PL 1961 The relationships between age, numbers of ocytes and fertility in virgin and multiparous mice. Journal of Endocrinology 21 469-495. (doi:10.1677/joe.0.0210469)

Kannisto P, Owman C \& Walles B 1985 Involvement of local adrenergic receptors in the process of ovulation in gonadotrophin-primed immature rats. Journal of Reproduction and Fertility 75 357-362. (doi:10.1530/ jrf.0.0750357)

Kermath BA \& Gore AC 2012 Neuroendocrine control of the transition to reproductive senescence: lessons learned from the female rodent model. Neuroendocrinology 96 1-12. (doi:10.1159/000335994)

Kermath BA, Riha PD, Woller MJ, Wolfe A \& Gore AC 2014 Hypothalamic molecular changes underlying natural reproductive senescence in the female rat. Endocrinology 155 3597-3609. (doi:10.1210/en.2014-1017)

Kotani M, Detheux M, Vandenbogaerde A, Communi D, Vanderwinden JM, Le Poul E, Brezillon S, Tyldesley R, Suarez-Huerta N, Vandeput F et al. 2001 The metastasis suppressor gene KiSS-1 encodes kisspeptins, the natural ligands of the orphan G protein-coupled receptor GPR54. Journal of Biological Chemistry 276 34631-34636. (doi:10.1074/jbc.M104847200)

Lansdown A \& Rees DA 2012 The sympathetic nervous system in polycystic ovary syndrome: a novel therapeutic target? Clinical Endocrinology 77 791-801. (doi:10.1111/cen.12003)

Laoharatchatathanin T, Terashima R, Yonezawa T, Kurusu S \& Kawaminami M 2015 Augmentation of metastin/kisspeptin mRNA expression by the proestrous luteinizing hormone surge in granulosa cells of rats: implications for luteinization. Biology of Reproduction 93 15. (doi:10.1095/biolreprod.115.127902)

Lara HE, McDonald JK, Ahmed CE \& Ojeda SR 1990a Guanethidinemediated destruction of ovarian sympathetic nerves disrupts ovarian development and function in rats. Endocrinology 127 2199-2209. (doi:10.1210/endo-127-5-2199)

Lara HE, McDonald JK \& Ojeda SR 1990b Involvement of nerve growth factor in female sexual development. Endocrinology 126 364-375. (doi:10.1210/endo-126-1-364)

Lara HE, Ferruz JL, Luza S, Bustamante DA, Borges Y \& Ojeda SR 1993 Activation of ovarian sympathetic nerves in polycystic ovary syndrome. Endocrinology 133 2690-2695. (doi:10.1210/endo.133.6.7902268)

Lara HE, Dissen GA, Leyton V, Paredes A, Fuenzalida H, Fiedler JL \& Ojeda SR 2000 An increased intraovarian synthesis of nerve growth factor and its low affinity receptor is a principal component of steroidinduced polycystic ovary in the rat. Endocrinology 141 1059-1072. (doi:10.1210/endo.141.3.7395)

Lara HE, Dorfman M, Venegas M, Luza SM, Luna SL, Mayerhofer A, Guimaraes MA, Rosa ESAA \& Ramirez VD 2002 Changes in sympathetic nerve activity of the mammalian ovary during a normal estrous cycle and in polycystic ovary syndrome: Studies on norepinephrine release. Microscopy Research and Technique 59 495-502. (doi:10.1002/jemt.10229)

Laszlovszky I \& Erdo SL 1983 Characterization of beta-adrenergic receptors in rat ovary. European Journal of Pharmacology 96 101-104. (doi:10.1016/0014-2999(83)90534-4)

Lawrence IE Jr \& Burden HW 1980 The origin of the extrinsic adrenergic innervation to the rat ovary. Anatomical Record 196 51-59. (doi:10.1002/ ar.1091960106)
Leon S, Barroso A, Vazquez MJ, Garcia-Galiano D, Manfredi-Lozano M, Ruiz-Pino F, Heras V, Romero-Ruiz A, Roa J, Schutz G et al. 2016 Direct actions of kisspeptins on GnRH neurons permit attainment of fertility but are insufficient to fully preserve gonadotropic axis activity. Scientific Reports 6 19206. (doi:10.1038/srep19206)

Lerner SP, Meredith S, Thayne WV \& Butcher RL 1990 Age-related alterations in follicular development and hormonal profiles in rats with 4-day estrous cycles. Biology of Reproduction 42 633-638. (doi:10.1095/ biolreprod42.4.633)

Lu KH, Hopper BR, Vargo TM \& Yen SS 1979 Chronological changes in sex steroid, gonadotropin and prolactin secretions in aging female rats displaying different reproductive states. Biology of Reproduction 21 193-203. (doi:10.1095/biolreprod21.1.193)

Mandl AM \& Shelton M 1959 A quantitative study of oocytes in young and old nulliparous laboratory rats. Journal of Endocrinology 18 444-450. (doi:10.1677/joe.0.0180444)

Marcondes FK, Bianchi FJ \& Tanno AP 2002 Determination of the estrous cycle phases of rats: some helpful considerations. Brazilian Journal of Biology 62 609-614. (doi:10.1590/S1519-69842002000400008)

Mathews TJ \& Hamilton BE 2016 Mean age of mothers is on the rise: United States, 2000-2014. NCHS Data Brief 1-8.

Mattheij JA \& Swarts JJ 1991 Quantification and classification of pregnancy wastage in 5-day cyclic young through middle-aged rats. Lab Animal 25 30-34. (doi:10.1258/002367791780808202)

Mayerhofer A, Dissen GA, Costa ME \& Ojeda SR 1997 A role for neurotransmitters in early follicular development: induction of functional follicle-stimulating hormone receptors in newly formed follicles of the rat ovary. Endocrinology 138 3320-3329. (doi:10.1210/endo.138.8.5335)

McGee EA \& Hsueh AJ 2000 Initial and cyclic recruitment of ovarian follicles. Endocrine Reviews 21 200-214. (doi:10.1210/er.21.2.200)

Merhi Z, Thornton K, Bonney E, Cipolla MJ, Charron MJ \& Buyuk E 2016 Ovarian kisspeptin expression is related to age and to monocyte chemoattractant protein-1. Journal of Assisted Reproduction and Genetics 33 535-543. (doi:10.1007/s10815-016-0672-x)

Merry BJ \& Holehan AM 1979 Onset of puberty and duration of fertility in rats fed a restricted diet. Journal of Reproduction and Fertility $\mathbf{5 7}$ 253-259. (doi:10.1530/jrf.0.0570253)

Messager S, Chatzidaki EE, Ma D, Hendrick AG, Zahn D, Dixon J, Thresher RR, Malinge I, Lomet D, Carlton MB et al. 2005 Kisspeptin directly stimulates gonadotropin-releasing hormone release via G protein-coupled receptor 54. PNAS 102 1761-1766. (doi:10.1073/ pnas.0409330102)

Moon CE, Bertero MC, Curry TE, London SN, Muse KN, Sharpe KL \& Vernon MW 1993 The presence of luteinized unruptured follicle syndrome and altered folliculogenesis in rats with surgically induced endometriosis. American Journal of Obstetrics and Gynecology 169 676-682. (doi:10.1016/0002-9378(93)90642-V)

Moran C, Morales L, Quiroz U \& Dominguez R 2000 Effects of unilateral or bilateral superior ovarian nerve section in infantile rats on follicular growth. Journal of Endocrinology 166 205-211. (doi:10.1677/joe.0.1660205)

Muir AI, Chamberlain L, Elshourbagy NA, Michalovich D, Moore DJ, Calamari A, Szekeres PG, Sarau HM, Chambers JK, Murdock P et al. 2001 AXOR12, a novel human G protein-coupled receptor, activated by the peptide KiSS-1. Journal of Biological Chemistry 276 28969-28975. (doi:10.1074/jbc.M102743200)

Neal-Perry G, Lebesgue D, Lederman M, Shu J, Zeevalk GD \& Etgen AM 2009 The excitatory peptide kisspeptin restores the luteinizing hormone surge and modulates amino acid neurotransmission in the medial preoptic area of middle-aged rats. Endocrinology 150 3699-3708. (doi:10.1210/en.2008-1667)

Nelson JF, Gosden RG \& Felicio LS 1985 Effect of dietary restriction on estrous cyclicity and follicular reserves in aging C57BL/6) mice. Biology of Reproduction 32 515-522. (doi:10.1095/biolreprod32.3.515)

Niggeschulze A \& Kast A 1994 Maternal age, reproduction and chromosomal aberrations in Wistar derived rats. Lab Animal 28 55-62. (doi:10.1258/002367794781065717)

Nishijima K, Tanaka S, Sakamoto SH, Kuwahara S, Ohno T \& Kitajima S 2013 Populations of follicles in F344/N rats during aging. Reproductive Biology 13 145-149. (doi:10.1016/j.repbio.2013.03.003)

Paredes AH, Salvetti NR, Diaz AE, Dallard BE, Ortega HH \& Lara HE 2011 Sympathetic nerve activity in normal and cystic follicles from isolated bovine ovary: local effect of beta-adrenergic stimulation on 
steroid secretion. Reproductive Biology and Endocrinology 966. (doi:10.1186/1477-7827-9-66)

Peluso JJ, Steger RW, Huang H \& Meites J 1979 Pattern of follicular growth and steroidogenesis in the ovary of aging cycling rats. Experimental Aging Research 5 319-333. (doi:10.1080/03610737908257208)

Peng MT \& Huang HH 1972 Aging of hypothalamic-pituitary-ovarian function in the rat. Fertility and Sterility 23 535-542. (doi:10.1016/ S0015-0282(16)39131-2)

Pinilla L, Aguilar E, Dieguez C, Millar RP \& Tena-Sempere M 2012 Kisspeptins and reproduction: physiological roles and regulatory mechanisms. Physiological Reviews 92 1235-1316. (doi:10.1152/ physrev.00037.2010)

Ricu MA, Ramirez VD, Paredes AH \& Lara HE 2012 Evidence for a celiac ganglion-ovarian kisspeptin neural network in the rat: intraovarian anti-kisspeptin delays vaginal opening and alters estrous cyclicity. Endocrinology 153 4966-4977. (doi:10.1210/en.2012-1279)

Richardson SJ, Senikas V \& Nelson JF 1987 Follicular depletion during the menopausal transition: evidence for accelerated loss and ultimate exhaustion. Journal of Clinical Endocrinology and Metabolism 65 1231-1237. (doi:10.1210/jcem-65-6-1231)

Rosa ESA, Guimaraes MA, Padmanabhan V \& Lara HE 2003 Prepubertal administration of estradiol valerate disrupts cyclicity and leads to cystic ovarian morphology during adult life in the rat: role of sympathetic innervation. Endocrinology 144 4289-4297. (doi:10.1210/en.2003-0146)

Rubin BS 2000 Hypothalamic alterations and reproductive aging in female rats: evidence of altered luteinizing hormone-releasing hormone neuronal function. Biology of Reproduction 63 968-976. (doi:10.1095/ biolreprod63.4.968)

Schmidt L, Sobotka T, Bentzen JG, Nyboe Andersen A \& ESHRE Reproduction and Society Task Force 2012 Demographic and medical consequences of the postponement of parenthood. Human Reproduction Update 18 29-43. (doi:10.1093/humupd/dmr040)

Sherwood A, Park SB, Hughes JW, Blumenthal JA, Hinderliter A, Trivedi R \& McFetridge-Durdle J 2010 Cardiovascular hemodynamics during stress in premenopausal versus postmenopausal women. Menopause $\mathbf{1 7}$ 403-409. (doi:10.1097/gme.0b013e3181b9b061)

Smirnova IO 1964 Luteinization of follicular cysts in rat ovaries resulting from the action of potassium iodide. Biulleten' Eksperimental'Noi Biologii I Meditsiny 57 94-98.

Sone K, Yamamoto-Sawamura T, Kuwahara S, Nishijima K, Ohno T, Aoyama H \& Tanaka S 2007 Changes of estrous cycles with aging in female F344/n rats. Experimental Animals 56 139-148. (doi:10.1538/ expanim.56.139)

Stefenson A, Owman C, Sjoberg NO, Sporrong B \& Walles B 1981 Comparative study of the autonomic innervation of the mammalian ovary, with particular regard to the follicular system. Cell and Tissue Research 215 47-62. (doi:10.1007/BF00236248)

te Velde ER 1998 Ovarian ageing and postponement of childbearing. Maturitas 30 103-104. (doi:10.1016/S0378-5122(98)00064-4)

Temel S, Lin W, Lakhlani S \& Jennes L 2002 Expression of estrogen receptoralpha and cFos in norepinephrine and epinephrine neurons of young and middle-aged rats during the steroid-induced luteinizing hormone surge. Endocrinology 143 3974-3983. (doi:10.1210/en.2002-220430)

Tomikawa J, Uenoyama Y, Ozawa M, Fukanuma T, Takase K, Goto T, Abe H, leda N, Minabe S, Deura C et al. 2012 Epigenetic regulation of Kiss1 gene expression mediating estrogen-positive feedback action in the mouse brain. PNAS 109 E1294-E1301. (doi:10.1073/pnas.1114245109)

Uenoyama Y, Nakamura S, Hayakawa Y, Ikegami K, Watanabe Y, Deura C, Minabe S, Tomikawa J, Goto T, leda N et al. 2015 Lack of pulse and surge modes and glutamatergic stimulation of luteinising hormone release in Kiss1 knockout rats. Journal of Neuroendocrinology 27 187-197. (doi:10.1111/jne.12257)

UniProt C 2015 UniProt: a hub for protein information. Nucleic Acids Research 43 D204-D212. (doi:10.1093/nar/gku989)

Waldenstrom U, Cnattingius S, Norman M \& Schytt E 2015 Advanced maternal age and stillbirth risk in nulliparous and parous women. Obstetrics and Gynecology 126 355-362. (doi:10.1097/ AOG.0000000000000947)

Westwood FR 2008 The female rat reproductive cycle: a practical histological guide to staging. Toxicologic Pathology 36 375-384. (doi:10.1177/0192623308315665)

Wilkosz P, Greggains GD, Tanbo TG \& Fedorcsak P 2014 Female reproductive decline is determined by remaining ovarian reserve and age. PLOS ONE 9 e108343. (doi:10.1371/journal.pone.0108343)

Wise PM 1984 Estradiol-induced daily luteinizing hormone and prolactin surges in young and middle-aged rats: correlations with age-related changes in pituitary responsiveness and catecholamine turnover rates in microdissected brain areas. Endocrinology 115 801-809. (doi:10.1210/ endo-115-2-801)

Wu JM, Zelinski MB, Ingram DK \& Ottinger MA 2005 Ovarian aging and menopause: current theories, hypotheses \& research models. Experimental Biology and Medicine 230 818-828.

Yin W \& Gore AC 2006 Neuroendocrine control of reproductive aging: roles of GnRH neurons. Reproduction 131 403-414. (doi:10.1530/ rep.1.00617)

Zhang X, Zhang L, Huo S, Wang J \& Cui S 2010 Neonatal superior ovarian nerve transection inhibits follicle development by enhancing follicular atresia and suppressing granulosa cell proliferation in rats. Reproduction Fertility and Development 22 1148-1158. (doi:10.1071/RD09271)

Zhou Q, Chen H, Yang S, Li Y, Wang B, Chen Y \& Wu X 2014 High-fat diet decreases the expression of Kiss1 mRNA and kisspeptin in the ovary, and increases ovulatory dysfunction in postpubertal female rats. Reproductive Biology and Endocrinology 12 127. (doi:10.1186/14777827-12-127)

Received 4 March 2016

First decision 12 April 2016

Revised manuscript received 21 October 2016

Accepted 31 October 2016 